\title{
HIGH RESOLUTION IMAGISTIC METHODS FOR DETECTION OF TEGUMENTAR PERFORATORS THAT CAN BE USED IN RECONSTRUCTION SURGERY OF TISSUE DEFECTS. PIG EXPERIMENTAL MODEL.
}

\author{
Bogdan CHIROIU*, MD \\ Professor Alexandru GEORGESCU**, PhD \\ Assistant lleana MATEI**, PhD \\ Professor Stelian PETCU ${ }^{\star \star \star}, P h D$ \\ Professor lonel PAPUC ${ }^{\star \star \star *}, P h D$ \\ Lecturer Radu LĂCĂTUŞ***, PhD
}

\begin{abstract}
Tissue defects still determine a high surgical interest in finding new and more efficient methods of covering. Perforator flaps are considered one of the most important methods of reconstruction, for defects all over the body. Anatomists, surgeons, radiologists are fervently searching ways to improve their reliability and also strategies to ensure that the chosen flap to be used is the best for that case. It has been proven that tissue defects' reconstruction involves knowing the exact anatomy and physiology of various vascular sources, but there are still unknown factors that sometimes induce perforator flaps failure.

Objective: The aim of this study is to identify and evaluate by two imagistic methods the perforator vessels in an experimental model of perforator flaps in pig.

Methods: The imagistic method employed was the X-ray angiography and Color Doppler vascular ultrasonography with high performance equipment. The explored perforators were located on the body of the experimental model, that was divided in 9 regions and the comparison was made between the perforators identified by imagistic methods and by microsurgical careful dissection.

Results: This study revealed that the average sensibility of ultrasound per region was $52.66 \%$ and the average sensibility of angiography per region was $35.30 \%$ on the entire lot.

Conclusion: The Color Doppler ultrasonography is a very reliable method for detection of the perforator vessels, with better results compared with X-ray angiography, detecting even the smaller perforators. So, the surgeon can rely the operative planning on this preoperative vascular exploration.
\end{abstract}

Keywords: perforator flap, perforator vessel, ultrasound, experimental, pig

* Clinic Hospital of Recuperation Cluj-Napoca, Deparment of Medical Imaging Radiology, chiroiubogdan@yahoo.com

** University of Medicine and Pharmacy "Iuliu Hațieganu" Cluj-Napoca, Department of Plastic Surgery

*** University of Medicine and Pharmacy "Iuliu Hațieganu" Cluj-Napoca, Department of Medical Imaging Radiology

**** University of Agricultural Sciences and Veterinary Medicine Cluj Napoca Faculty of Veterinary Medicine Cluj Napoca, Discipline of Semiology, Ethology and Diagnostic Imaging

Cluj Veterinary Journal, 15(1)/2009, pp. 50-56 


\section{Introduction}

Latest appearance in simple and complex tissue defect's reconstructive surgery, perforator flaps proved to be one of the most performant in the field. That is because of the great advantage they offer: the posibility to harvest only the cutaneous island, completely excluding the muscle component from the flap. It is still necesary to identify posible vascular sources for this type of flaps and also to map them comprehensively. Nowadays, the most recent imagistic methods allow the visualization of the skin micro-circulation and their mapping. The study of this experimental model in pig will allow a comparison with the already performed rat experimental model, and the results of this study will offer the basis for other experimental models in fresh human cadavers, aimed to improve the techniques and tactics of tissue defects reconstructive surgery.

\section{Material and Methods}

The study was performed during the ANGIOCART research grant, that included as partners UMF Iuliu Hatieganu Cluj Napoca, USAMV Cluj Napoca, ICIA Cluj Napoca and ISP Cluj Napoca.

In the experimental study was created a lot of 10 PIC - F II - 337 pigs, with comparable characteritics: age (15-16 weeks), wheight (50-55kg), dimensions (length 70-80 cm, thoracal circonference: 70-75 cm, abdominal circonference: 85-90 cm).

The preoperative investigations included the detection of perforator vessels using Color and Power Doppler ultrasonography and contrast angiography of different skin areas, the same in all the experimental subjects. After the perforator mapping followed their microsurgical detection through dissection. The results from the ultrasonography and the angiography were noted in the individual subject's charts, and then were corelated with the surgical disection ones.

In order to carefully establish the number of perforators in a designated anatomical area and their precise location, it was necessary to divide the pig's body surface in some virtual interesting topographic regions. The head, tail, ears and distal anterior and posterior extremities were excluded from the study.

The remaining body surface was divided in 9 topographic regions, delimitated by specific anatomical points. These regions are:

- cervical region

- thoracic paravertebral region

- thoracic region

- anterior limb proximal region

- anterior limb distal region

- lumbar paravertebral region

- abdominal region

- posterior limb proximal region

- posterior limb distal region.

In turn, these topographic regions were divided in equal square quadrants of 10/10 $\mathrm{cm}$ in the cervical, thoracic paravertebral, thoracic, anterior limb proximal, lumbar paravertebral, abdominal, posterior limb proximal regions, and in $5 / 5 \mathrm{~cm}$ equal square quadrants in the anterior and posterior limb distal regions. Every region comprised a specific number of quadrants, numbered longitudinally with letters, starting with A (from the pubic bone) to K (at the menton), and transversally with Arabic numbers, starting with 1 (at the median ventral line) to 5 (near the dorsal median line). In this manner, every identified perforator was carefully placed in one of these quadrants. 


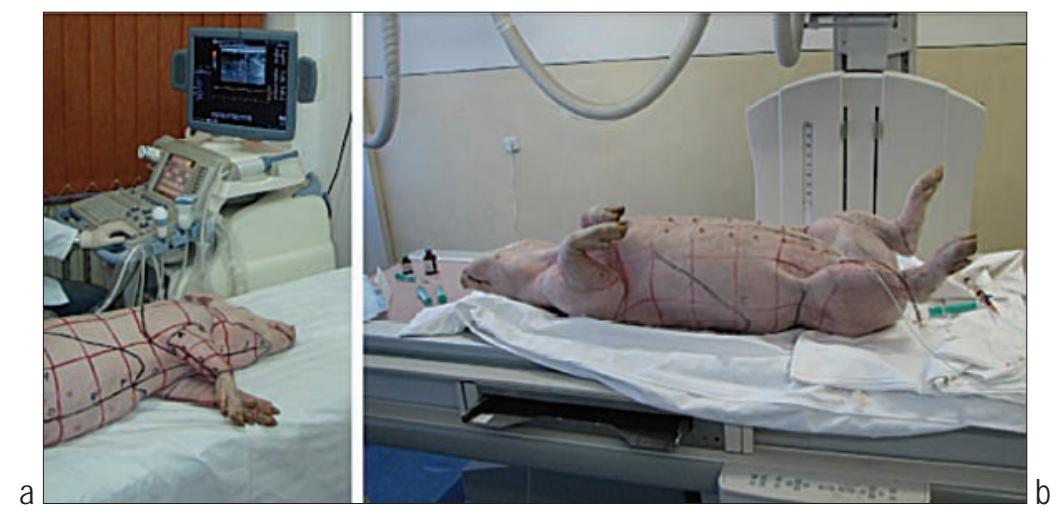

Fig. 1. Color Doppler ultrasonography investigation (a) and angiography (b)

For the preoperative vascular investigations the pigs received intramuscular neurolept-analgesy with hydrocloric xilazine $20 \mathrm{mg} / \mathrm{ml}$, azaperona $40 \mathrm{mg} / \mathrm{ml}$ and hidrocloric ketamin $100 \mathrm{mg} / \mathrm{ml}$ of veterinary use. These drugs offer rapid anesthesia and analgesia, effective in about 10 minutes. The analgesic drug was administered 5-10 minutes after the neuroleptic drug. The amounts administered were $0.1-0.2 \mathrm{ml} / \mathrm{kgc}(2-4 \mathrm{mg} / \mathrm{kgc})$ hydrocloric xilazine or $0.05 \mathrm{ml} / \mathrm{kgc}(2 \mathrm{mg} / \mathrm{kgc})$ azaperona and $0.1 \mathrm{ml} /$ kgc (10 mg/kgc) hidrocloric ketamin. The administration of anesthetic was repeated every 15 minutes for about 3 hours (the average time for the vascular examination of the entire subject's body surface). During the anesthesia the subject's body temperature was monitored and kept constant. The heart and respiratory rate were monitored every 10 minutes.

The pigs were identified by the registration number on the ear tag, were washed with warm water and soap, were sedated, then shaved and positioned in decubitus, without immobilization.

The ultrasonic evaluation was performed with the help of a performing, last generation device 2008 GE Logiq 9, with linear high resolution transductors with variable frequency 9-14 MHz.

The angiography was performed using a SIEMENS Coroskop Top model C-arm angiograph, with digital acquisition of images (DAS - Digital Acquisition System), image enhancement possibilities, digital video acquisition of images (DCM - Digital Cine Mode) and serigraphy and a Philips Duodiagnostic X-ray device with digital acquisition of images on phosforiq plates PCR Eleva S.

The cutaneous projection of the perforator was noted on the skin with a permanent marker and then charted on the individual subject's map.

\section{Results and discussions}

After the imagistic vascular examination of the 10 subjects, the data regarding the perforator location and their cutaneous projection were centralized, taking into consideration the 9 topographic regions and the maping quadrants.
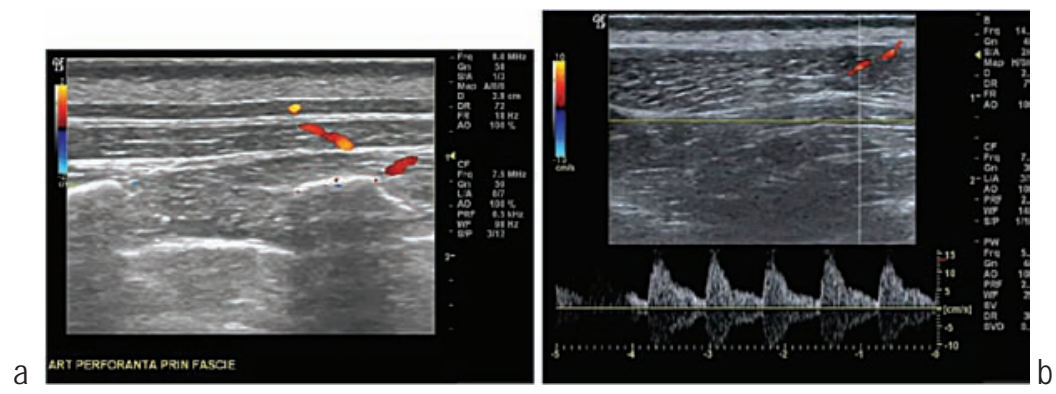

Fig. 2. Perforator vessel identified using Color Doppler ultrasonography (a) and the determination of arterial or venous nature of the vessel using pulse Doppler technique (b) 


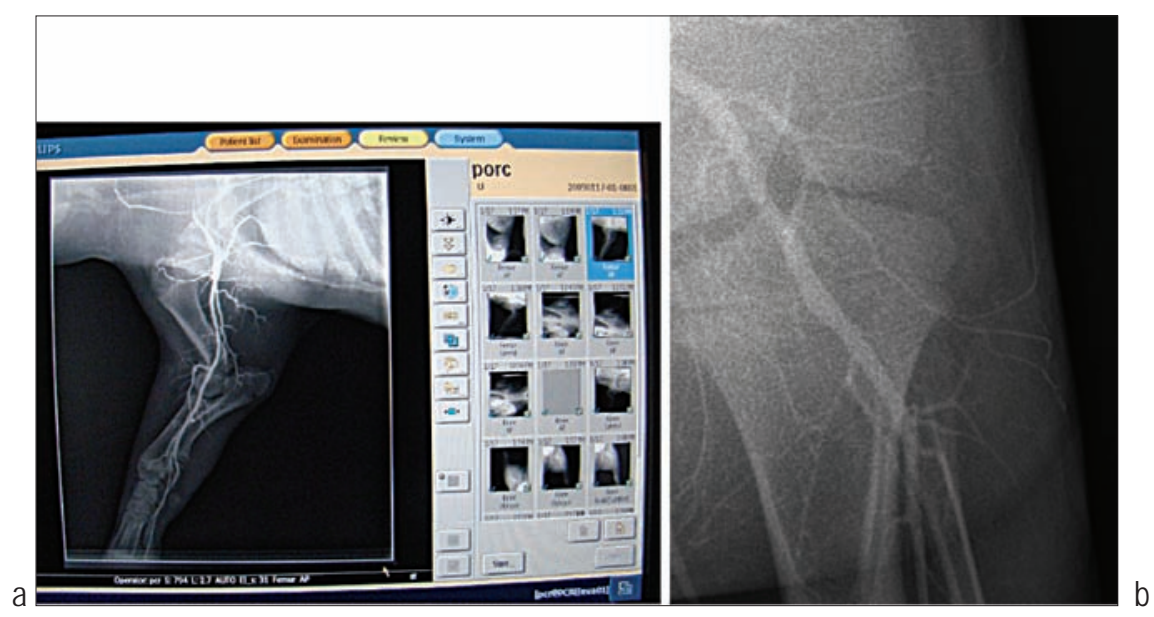

Fig. 3. Digital angiography: (a) anterior limb, (b) posterior limb (enhanced)

These data were correlated with the ones obtained through minute surgical disection.

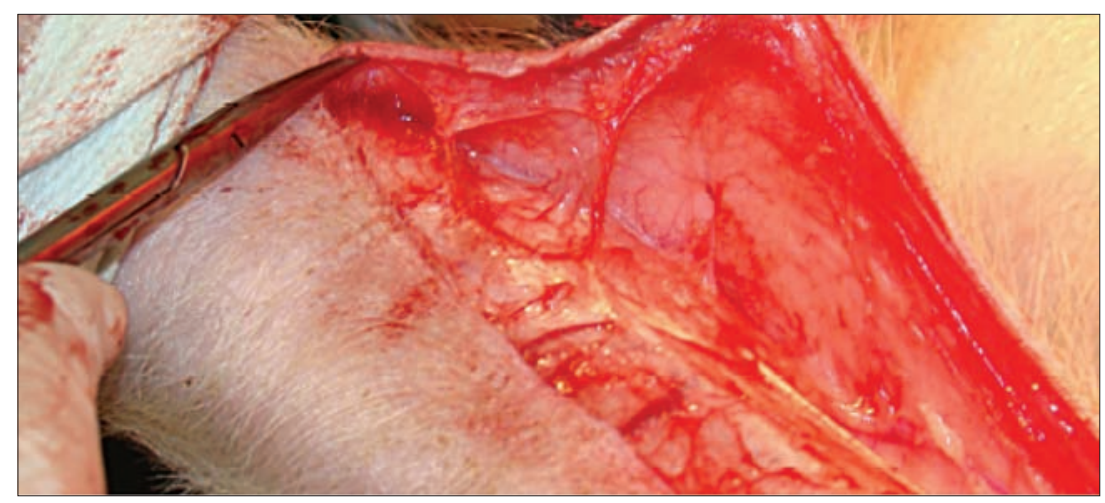

Fig. 4. Perforators identified by micro-dissection

All the data were included in tables containing the number of perforator vessels identified by imagistic explorations per topographic quadrant, in tables comparing the imagistic versus surgical detection etc.

Table 1. Example of data centralization table showing the number of perforator vessels identified by vascular preoperative imaging and the topographic quadrant (in the lumbar paravertebral region)

\begin{tabular}{|c|c|c|c|c|c|c|c|}
\hline Porc & Cadran & B4 & $\mathrm{C} 4$ & $\mathrm{C5}$ & D4 & D5 & Total vase \\
\hline & Arie partiala $\%$ & 30 & 80 & 10 & 70 & 20 & \\
\hline 1 & LOT I & 1 & 5 & 2 & 3 & 1 & 12 \\
\hline 2 & LOT I & 1 & 5 & 0 & 3 & 1 & 10 \\
\hline 3 & LOT I & 1 & 5 & 2 & 3 & 0 & 11 \\
\hline 4 & LOT I & 1 & 5 & 2 & 3 & 1 & 12 \\
\hline 5 & LOT I & 1 & 5 & 1 & 3 & 1 & 11 \\
\hline 6 & LOT I & 0 & 5 & 2 & 1 & 1 & 9 \\
\hline 7 & LOT I & 1 & 5 & 2 & 3 & 1 & 12 \\
\hline 8 & LOT I & 0 & 5 & 2 & 3 & 1 & 11 \\
\hline 9 & LOT I & 0 & 5 & 2 & 2 & 1 & 10 \\
\hline \multirow[t]{3}{*}{10} & LOT I & 1 & 5 & 2 & 3 & 0 & 11 \\
\hline & TOTAL VASE DETECTATE & 7 & 50 & 17 & 27 & 8 & \\
\hline & & B4 & $\mathrm{C} 4$ & C5 & D4 & D5 & \\
\hline
\end{tabular}


Table 2. Example of data centralization table showing the comparison between the preoperative imagistic investigations and the surgical dissection results and the sensibility determination in the thoracic paravertebral region

\begin{tabular}{|c|c|c|c|c|c|c|c|c|c|c|c|c|}
\hline Porc & \begin{tabular}{l|l} 
Metoda & Cadran \\
\end{tabular} & E4 & E5 & $\overline{F 4}$ & F5 & G4 & G5 & $\mathrm{H} 4$ & $\mathrm{H5}$ & I4 & Total & Se porc \\
\hline & Arie partiala $\%$ & 70 & 40 & 70 & 30 & 70 & 20 & 70 & 10 & 20 & & \\
\hline \multirow{2}{*}{1} & Angiografic & 1 & 0 & 0 & 1 & 2 & 0 & 1 & 0 & 0 & 5 & \multirow{2}{*}{$19,23 \%$} \\
\hline & Intraoperator & 6 & 3 & 0 & 3 & 3 & 1 & 7 & 0 & 3 & 26 & \\
\hline \multirow{2}{*}{2} & Angiografic & 1 & 0 & 0 & 0 & 2 & 0 & 1 & 0 & 0 & 4 & \multirow{2}{*}{$14,28 \%$} \\
\hline & Intraoperator & 6 & 3 & 0 & 4 & 4 & 2 & 7 & 0 & 2 & 28 & \\
\hline \multirow{2}{*}{3} & Angiografic & 1 & 0 & 0 & 1 & 2 & 0 & 1 & 0 & 0 & 5 & \multirow{2}{*}{$21,73 \%$} \\
\hline & Intraoperator & 5 & 2 & 0 & 3 & 2 & 2 & 6 & 0 & 3 & 23 & \\
\hline \multirow{2}{*}{4} & Angiografic & 0 & 0 & 0 & 1 & 2 & 0 & 0 & 0 & 0 & 3 & \multirow{2}{*}{$11,11 \%$} \\
\hline & Intraoperator & 6 & 2 & 1 & 3 & 3 & 1 & 7 & 0 & 4 & 27 & \\
\hline \multirow[b]{2}{*}{5} & Angiografic & 0 & 0 & 0 & 1 & 2 & 0 & 0 & 0 & 0 & 3 & \multirow{2}{*}{$12 \%$} \\
\hline & Intraoperator & 5 & 2 & 0 & 4 & 3 & 1 & 7 & 0 & 3 & 25 & \\
\hline \multirow{2}{*}{6} & Angiografic & 1 & 0 & 0 & 1 & 2 & 0 & 1 & 0 & 0 & 5 & \multirow{2}{*}{$17,85 \%$} \\
\hline & Intraoperator & 6 & 4 & 0 & 2 & 4 & 1 & 7 & 0 & 4 & 28 & \\
\hline \multirow{2}{*}{7} & Angiografic & 0 & 0 & 0 & 1 & 2 & 0 & 1 & 0 & 0 & 4 & \multirow{2}{*}{$16,66 \%$} \\
\hline & Intraoperator & 5 & 4 & 0 & 2 & 2 & 1 & 7 & 1 & 2 & 24 & \\
\hline \multirow{2}{*}{8} & Angiografic & 1 & 0 & 0 & 0 & 2 & 0 & 1 & 0 & 0 & 4 & \multirow{2}{*}{$18,18 \%$} \\
\hline & Intraoperator & 6 & 3 & 0 & 2 & 2 & 0 & 7 & 0 & 2 & 22 & \\
\hline \multirow{2}{*}{9} & Angiografic & 1 & 0 & 0 & 1 & 2 & 0 & 0 & 0 & 0 & 4 & \multirow{2}{*}{$14,81 \%$} \\
\hline & Intraoperator & 7 & 3 & 0 & 4 & 2 & 1 & 8 & 0 & 2 & 27 & \\
\hline \multirow{8}{*}{10} & Angiografic & 0 & 0 & 0 & 1 & 2 & 0 & 1 & 0 & 0 & 4 & \multirow{2}{*}{$14,28 \%$} \\
\hline & Intraoperator & 6 & 4 & 0 & 2 & 3 & 2 & 7 & 0 & 4 & 28 & \\
\hline & \begin{tabular}{l|l} 
Metoda & Cadran \\
\end{tabular} & E4 & E5 & F4 & F5 & G4 & G5 & H4 & $\mathrm{H5}$ & I4 & Total & Se porc \\
\hline & $\begin{array}{c}\text { Total vase } \\
\text { Angiografic }\end{array}$ & 6 & 0 & 0 & 8 & 20 & 0 & 7 & 0 & 0 & 41 & \\
\hline & $\begin{array}{c}\text { Total vase } \\
\text { intraoperator }\end{array}$ & 58 & 30 & 1 & 29 & 28 & 12 & 70 & 1 & 29 & 258 & \\
\hline & M1 cadran & 0,6 & 0 & 0 & 0,8 & 2 & 0 & 0,7 & 0 & 0 & 4,1 & \\
\hline & M2 cadran & 5,80 & 3 & 0,1 & 2,9 & 2,8 & 1,2 & 7 & 0,1 & 2,9 & 25,8 & \\
\hline & Se cadran & $\begin{array}{c}10,34 \\
\%\end{array}$ & 0 & 0 & $\begin{array}{c}27,58 \\
\%\end{array}$ & $\begin{array}{c}71,42 \\
\%\end{array}$ & 0 & $10 \%$ & 0 & 0 & $\begin{array}{c}15,89 \\
\%\end{array}$ & Se regiune \\
\hline
\end{tabular}

Also, were performed comprehensive maps showing the imagistic versus surgical averages.
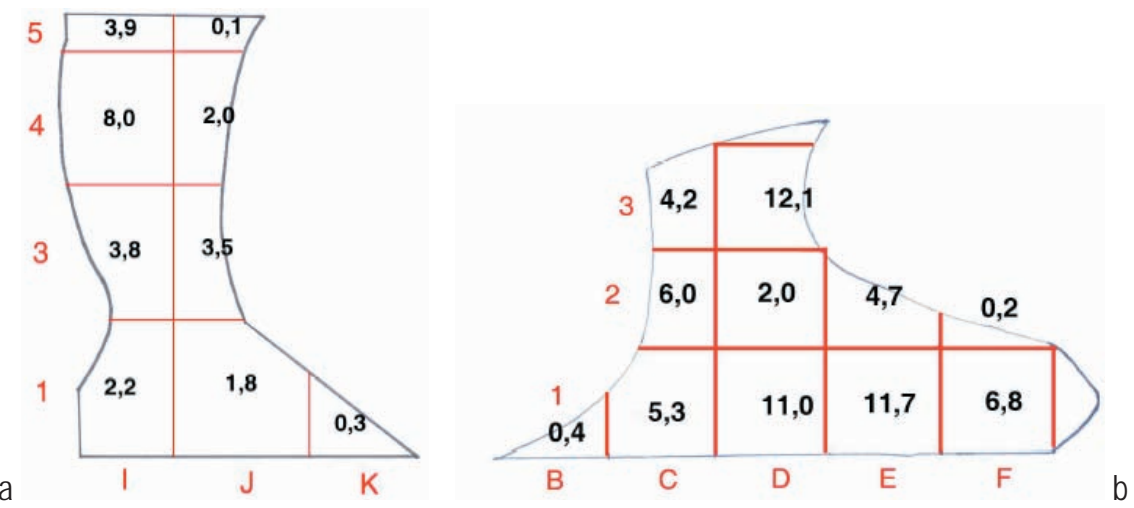

Fig. 5. Perforator detection averages in the cervical (a) and abdominal (b) regions

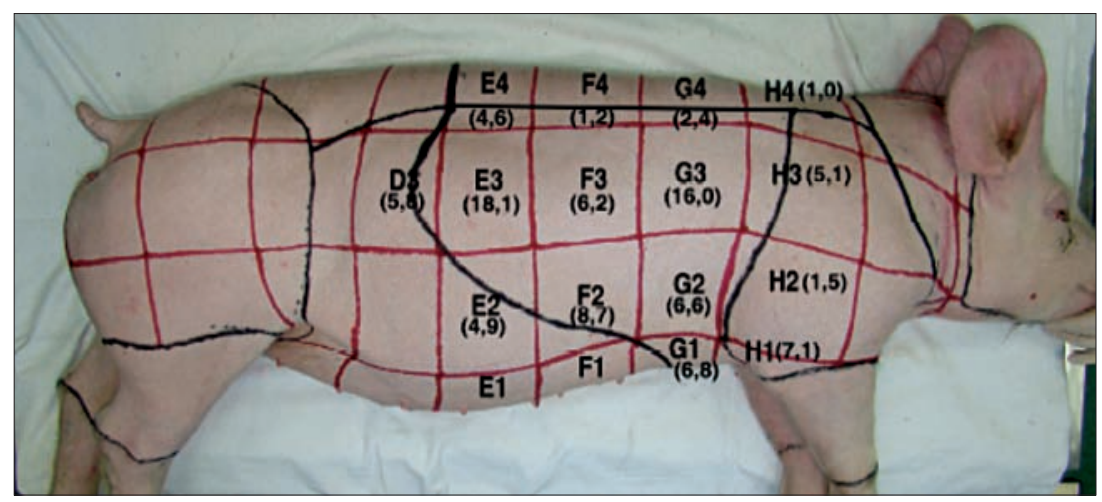

Fig. 6. Perforator detection averages in the thoracic region 
The high resolution Color and Power Doppler ultrasonography and angiography were used in the study of all the subjects. The ultrasonography and angiography detection averages for every region, quadrant and subject were calculated. Also, the sensibility of the methods was calculated for every topographic quadrant and subject, and then the general average was calculated per region for the entire lot of experimental animals: „Detection sensibility per topographic quadrant” (Se/quadrant), „Individual detection sensibility per pig” (Se/pig), “Detection sensibility per region” (Se/region).

The centralized results showed the fact that Rezultatele centralizate au pus în evidenţă faptul că Se/region obtained using the ultrasonography investigation has an average of $52.66 \%$, with values between $15.64 \%$ (in the distal region of the anterior limb, area difficult to explore) and $76.76 \%$ (in the proximal region of the posterior limb - internal aspect), and the Se/region obtained through the angiography study has an average value of $35.30 \%$, with values between $13.40 \%$ and $58.41 \%$.

It was considered that the significantly different results provided by these two methods were due to the fact that the angiography could detect only the large caliber perforators, and in some cases their location was not very accurate due to method's limitations (the maximum amount of contrast substance did not allow the examination of every topographic area in more than 2-3 planes).

\section{Conclusions}

In pig there are a large number of perforator vessels that can represent a very good asset in experimental studies, both involving imagistic vascular studies and micro-surgical training. These cutaneous perforators offer still the possibility to create new experimental models, and perfecting the methods of preoperative detection can be a very important corollary of this type of surgery.

The ultrasonography, a non-invasive, universally spread method, is one of the first choice investigations in the preoperative detection of perforator vessels. The Color Doppler ultrasonography is a more fiable method in the detection of perforators, but also in the post-surgical surveilance of the flap's evolution. The Doppler ultrasonography proved to have an average sensibility rate of 53.66\%, superior to the angiography's sensibility average, of $35.30 \%$, thus being a trust worthy method in detecting a perforator signal, keeping in mind that it can miss some perforators that can be identified by surgical dissection. Due to its high level sensibility and specificity, it has become the major investigation in the preoperative detection of perforators.

Nevertheless, the Color Doppler ultrasonography has the disadvantage that is dependent to the anatomical particularities of the region, thus some quadrants were difficult or impossible to explore (distal region of the anterior limb).

The arteriography was found to be useful in the preoperative determination of perforator vessels, but with some limitations: the vascular canulation was only possible distant to the actual site to be investigated, to preclude the perforator's damage. It is an invasive method and rather inaccurate in perforator location and qualities determination. Also, it has some other disadvantages: can detect only the large caliber perforators, and the patients find it difficult to bear it. It is possible that the intra-arterial injection of the contrast substance can influence the post-operative evolution of the harvested flaps. The number of injections and the maximum amount of contrast substance allowed to be administered in one session limited the examination for each area to 2-3 planes, every angle change needing a new injection.

The fact that the imagistic methods didn't detect the smaller perforator vessels did not impede the creation of the experimental model. 
The higher values of the ultrasonography exploration averages and its distinct advantages confirmed that it is the method of choice for the next stages of our study.

In conclusion, it can be stated that the pig is a very good experimental model, adequate for the study of perforator flaps, the pig presenting a skin perforator system with a relatively constant architecture.

\section{References}

1. Blondeel PN, Morris SF, Hallock GG, Neligan P. Perforator Flaps: Anatomy, Technique and Clinical Applications. Vol. 2. 1st ed. St. Louis,MO: Quality Medical Publishing; 2006:1042

2. Chiroiu B., Georgescu Al., Petcu S., Papuc I., Lacatus R., Matei I.Explorări imagistice de înaltă rezoluţie a vaselor perforante tegumentare folosite în chirurgia reconstructiva a defectelor de substanţă. Model experimental pe sobolan -Lucrari stiintifice seria Medicina Veterinara. 2009;52(11):451-458

3. El-Mrakby HH, Milner RH. The vascular anatomy of the lower anterior abdominal wall: a microdissection study on the deep inferior epigastric vessels and the perforator branches. Plast Reconstr Surg. 2002;109:539-543.

4. Falca C., Ciorba GH.: Tehnici de examinare clinică si paraclinică la animale, editia a II-a, Editura Mirton, Timisoara, 2005

5. Forbes PD.Vascular supply of the skin and hair in swine, in Montagna W. and Dobson RL., Advances in Biology of the Skin. Pergamon, New York. 1969.

6. Kerrigan CL., Zelt RG., Thompson JG., Diano E.:The pig as an experimental animal in plastic surgery research for the study of skin flaps, myocutaneous flaps and fasciocutaneous flaps. Lab.Anim.Sci. pag.408-412, 1986

7. Knight KR., Collopy PA., O’Brien BMcC. Correlation of viability and laser Doppler Flowmetry in ischemic flaps. Journal of Reconstructive Surgery, (43), pag.444. 1987.

8. Kohn DH., Wixson SK., White WJ.: Anesthesia and Analgesia in Laboratory Animals. Academic Press, New York. 1997.

9. Matei I., Georgescu Al, Chiroiu B., et al Harvesting of forearm perforator flaps based on intraoperative vascular exploration: clinical experiences and literature review -. Microsurg 2008;28(5):321-330.

10.National Research Council. Subcommittee on Swine Nutrition.Nutrient Requirements of Swine. National Academy Press, Washington DC. 1998.

11.Papuc I., Lăcătus R.: Semiologie si imagistică medicală veterinară, Editura Accent, Cluj-Napoca, 2004.

12.Papuc I.: Anatomie comparată. Vascularizatia membrelor la unele mamifere pentadactile, Ed. Gedo, Cluj-Napoca, 2000.

13.Sack W.O. Essentials of Pig Anatomy and Horwitz/Kramer Atlas of Musculoskeletal Anatomy of the Pig. Veterinary Textbooks, Ithaca, New York. pag. 192, 1982.

14.Sasaki GH, Pang CY. Pathophysiology of skin flaps raised on expanded pig skin, Plast. Recontr. Surg., 74(1), pag.59-67. 1984.

15.Schaller O. Illustrated Veterinary Anatomical Nomenclature, Enke, Stuttgart, 1992. 